\title{
Bilateral adrenalectomy in the 21st century: when to use it for hypercortisolism?
}

\author{
Carole Guerin', David Taieb ${ }^{2}$, Giorgio Treglia ${ }^{3}$, Thierry Brue ${ }^{4}$, André Lacroix ${ }^{5}$, \\ Frederic Sebag' and Frederic Castinetti ${ }^{4}$
}

${ }^{1}$ Aix-Marseille University, Assistance Publique Hopitaux de Marseille, Department of Endocrine Surgery, La Conception Hospital, Marseille, France

${ }^{2}$ Aix-Marseille University, Assistance Publique Hopitaux de Marseille, Department of Nuclear Medicine, La Timone Hospital, Marseille, France

${ }^{3}$ Department of Nuclear Medicine, Thyroid and PET/CT Center, Oncology Institute of Southern Switzerland, Bellinzona and Lugano, Switzerland

${ }^{4}$ Aix-Marseille University, Assistance Publique Hopitaux de Marseille, Department of Endocrinology, La Conception Hospital, 147 Boulevard Baille, 13005 Marseille, France

${ }^{5}$ Endocrine Division, Department of Medicine, Centre hospitalier de l'Université de Montréal (CHUM), Montreal, Canada

\author{
Correspondence \\ should be addresses \\ to F Castinetti \\ Email \\ Frederic.castinetti@ap-hm.fr
}

\begin{abstract}
Therapeutic options available for the treatment of Cushing's syndrome (CS) have expanded over the last 5 years. For instance, the efficient management of severe hypercortisolism using a combination of fast-acting steroidogenesis inhibitors has been reported. Recent publications on the long-term efficacy of drugs or radiation techniques have also demonstrated low toxicity. These data should encourage endocrinologists to reconsider the place of bilateral adrenalectomy in patients with ACTH-dependent aetiologies of CS; similarly, the indication of bilateral adrenalectomy is reassessed in primary bilateral macronodular adrenal hyperplasia. The objective of this review is to compare the efficacy and side effects of the various therapeutic options of hypercortisolism with those of bilateral adrenalectomy, in order to better define its indications in the 21st century.
\end{abstract}

Keywords

- Cushing's syndrome

- Cushing's disease

- primary bilateral macronodular adrenal hyperplasia

- surgery
Endocrine-Related Cancer (2016) 23, R131-R142

\section{Introduction}

Hypercortisolism or Cushing's syndrome (CS) is a rare condition; effective treatments are necessary because of an increased morbidity and mortality if left untreated. CS can be due to: i) an excess of adrenocorticotrophin (ACTH) production leading to an increased production of cortisol; it can originate from a pituitary adenoma (Cushing's disease (CD)) or an extrapituitary endocrine tumour (ectopic ACTH secretion (EAS)); ii) an increased production of cortisol originating from a unilateral adrenal lesion (adenoma or carcinoma) or bilateral hyperplasias: primary bilateral macronodular adrenal hyperplasia $(\mathrm{BMAH})$, a condition in which adrenal production of ACTH and ARMC5 mutations have been recently evidenced (Assie et al. 2013, Louiset et al. 2013), or primary pigmented nodular adrenal disease (PPNAD) that is frequently due to mutations of PRKAR1A (Bertherat 2006).

All of these conditions apart from the unilateral adrenal tumours can benefit from bilateral adrenalectomy (BA) to cure hypercortisolism (Lacroix et al. 2015, Nieman et al. 2015).

Published by Bioscientifica Ltd 
The recent Endocrine Society Guidelines have not recommended BA as a first-line treatment of CS (Nieman et al. 2015). Long-term efficacy and safety of steroidogenesis inhibitors or new modalities of radiation techniques as a second-line treatment have been recently shown. Reports also emphasized the efficacy of fast-acting steroidogenesis inhibitors in acute severe hypercortisolism as a first-line treatment. One should thus wonder whether BA still has a role in the management of hypercortisolism. Therefore, the aim of this review is to identify the potential indications of $\mathrm{BA}$ in the updated therapeutic algorithms of CS; we give our opinion on its current and likely future roles, in order to help clinicians choose the best options for their patients (Fig. 1). Current evidence on optimal therapeutic strategies is scarce, and head-to-head comparisons are inexistent. While the mean age at diagnosis of $\mathrm{CD}$ is $40-50$ years, there are no follow-up data available for more than 10 years for medical therapies of hypercortisolism.

\section{Search strategy and selection criteria}

We searched the Cochrane Library and MEDLINE by using the terms 'adrenalectomy', 'bilateral adrenalectomy', 'adrenals', 'hypercortisolism', 'Cushing' or 'bilateral hyperplasia' from 1950 to 2015. We largely selected publications in English in the past 5 years but did not exclude commonly referenced and highly regarded older publications. We also searched the reference lists of articles identified by this search strategy and selected those that we judged to be relevant. Review articles and international guidelines are cited to provide readers with more details and more references than this review can allow. A pooled analysis was performed about outcome data and recurrence rate. For statistical pooling of the data, the DerSimonian and Laird method (random-effects model) was used. In this model, pooled data represent weighted averages related to the sample size of individual studies. Pooled data are presented as 95\% CI. Statistical analyses were performed using the StatsDirect statistical

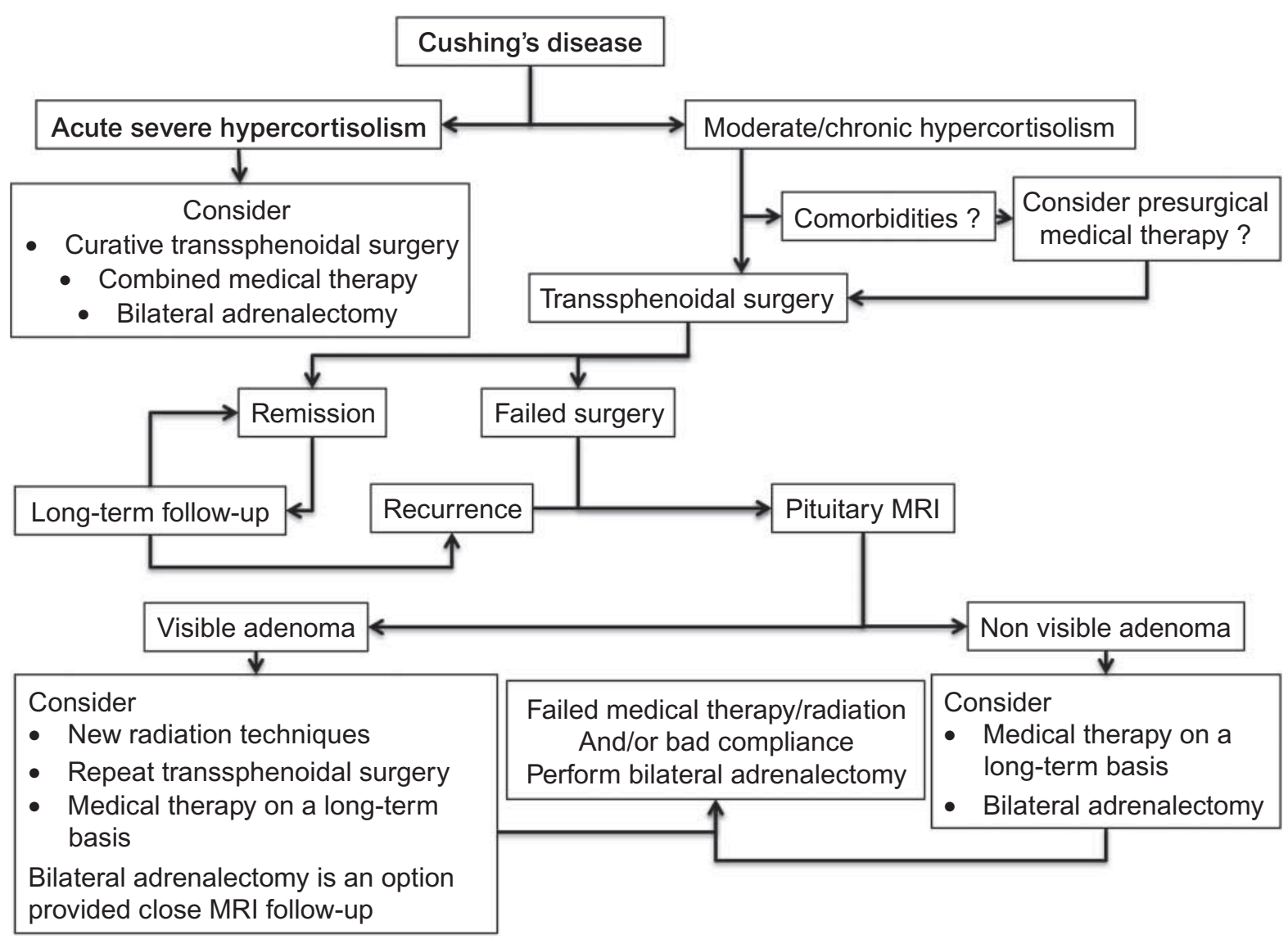

Figure 1

Suggested therapeutic algorithm in ACTH-dependent Cushing's syndrome. 
software version 2.8 (StatsDirect Ltd; Altrincham, UK). Literature data and pooled results are summarized in Tables 1, 2, 3, 4 and discussed below.

\section{The BA technique}

BA was first performed by open anterior laparotomy. Young (1936) then described a posterior approach by removing the 12th rib. Russell et al. (1982) compared the anterior and posterior approaches in unilateral or BA and showed that the complications induced by lombotomy were lower and led to less morbidity and a shorter hospital stay. Finally, Gagner et al. (1992) described the transperitoneal laparoscopic adrenalectomy, which has been improved since then and slightly modified by some teams with retroperitoneoscopy or robot-assisted surgery. The laparoscopic approach is now considered the gold standard for BA, as it results in less post-operative pain, decreased length of stay and faster recoveries. It is a safe procedure with $17-19 \%$ morbidity and 0-3\% mortality rates (Ritzel et al. 2013, Reincke et al. 2015). The use of lateral transperitoneal (LTP) vs posterior retroperitoneal (PRP) routes remains to be debated; whereas no significant difference was reported in terms of the associated postoperative complications, the PRP approach is preferred in patients with smaller tumours $(<6 \mathrm{~cm})$ and lower BMI $\left(<35 \mathrm{~kg} / \mathrm{m}^{2}\right.$ ) (Sharma et al. 2009, Miccoli et al. 2011, Lan et al. 2015). A significantly shorter operative time was reported for the PRP approach, but it was mainly due to the repositioning time in LTP, as two surgical teams could perform both adrenalectomies in the same time in PRP (Raffaelli et al. 2014, Lan et al. 2015).
Recently, robot-assisted BA was described without obvious advantages and a superior cost (Raffaelli et al. 2014).

\section{$B A$ in $C D$ and EAS}

The difficult management is illustrated by the broad range of clinical presentations, from rapidly severe signs in patients with very high cortisol levels (Nieman et al. 2015), to more insidious presentations with progressive onset of signs leading to a delayed diagnosis. Long-term exposure to hypercortisolism induces severe complications that are only partly reversible after remission (Ntali et al. 2013, Andela et al. 2015). The endocrinologist's goals are thus to make an earlier diagnosis, achieve a rapid control (within a few days) of cortisol levels in case of acute hypercortisolism and maintain long-term eucortisolism even when a definitive cure cannot be achieved. There are thus shortterm and long-term therapeutic challenges, and BA has potential roles in both situations. Recent reviews have summarized the merits and pitfalls of BA. However, these reviews were usually not comparing $\mathrm{BA}$ with other therapeutic options, especially in the setting of acute severe hypercortisolism, or as a final option in patients treated long-term (Bertagna \& Guignat 2013, Ritzel et al. 2013, Osswald et al. 2014, Katznelson 2015, Neychev et al. 2015, Reincke et al. 2015, Wong et al. 2015). We will focus our discussion on these specific points.

\section{BA in acute severe hypercortisolism}

Severe hypercortisolism is a life-threatening condition, particularly in patients with psychiatric symptoms.

Table 1 Main studies on the recurrence of adrenal remnants after bilateral adrenalectomy in the last 25 years

\begin{tabular}{|c|c|c|c|c|c|}
\hline References & Patients & $\begin{array}{l}\text { Persistent } \\
\text { adrenal } \\
\text { tissue }\end{array}$ & $\begin{array}{l}\text { Significant } \\
\text { clinical } \\
\text { recurrence }\end{array}$ & Time to recurrence & Subsequent treatment \\
\hline Chow et al. (2008) & 68 & NA & $2(2.9 \%)$ & $\begin{array}{l}\text { Not cured immediately } \\
\text { after surgery }\end{array}$ & Follow-up without treatment \\
\hline Nagesser et al. (2000) & 44 & $12(27.3 \%)$ & $2(4.5 \%)$ & Early relapse & $\begin{array}{l}\text { Additional surgery allowing } \\
\text { cure }(n=1), \text { follow-up } \\
\text { without treatment }(n=1)\end{array}$ \\
\hline Kemink et al. (1992) & 50 & $9(18 \%)$ & $1(2 \%)$ & 9 years & Transsphenoidal surgery \\
\hline Chalmers et al. (1981) & $5 *$ & 5 & 4 & $\begin{array}{l}1,2,3 \text { and } 7 \text { years } \\
\text { after the surgery }\end{array}$ & $\begin{array}{l}\text { Recurrence of Cushing's disease, } \\
\text { pituitary radiotherapy, } \\
5 \text { months and } 5 \text { years later } \\
(n=2) ; \text { pituitary radiotherapy } \\
(n=2) ; \text { still in remission } \\
4 \text { years after glucocorticoid } \\
\text { withdrawal }(n=1)\end{array}$ \\
\hline Pooled data $(95 \% \mathrm{Cl})$ & 162 & $23 \%(15-32 \%)$ & $3.8 \%(1.4-7.3 \%)$ & - & \\
\hline
\end{tabular}

*Five isolated case reports from five different centres. NA, not available. 

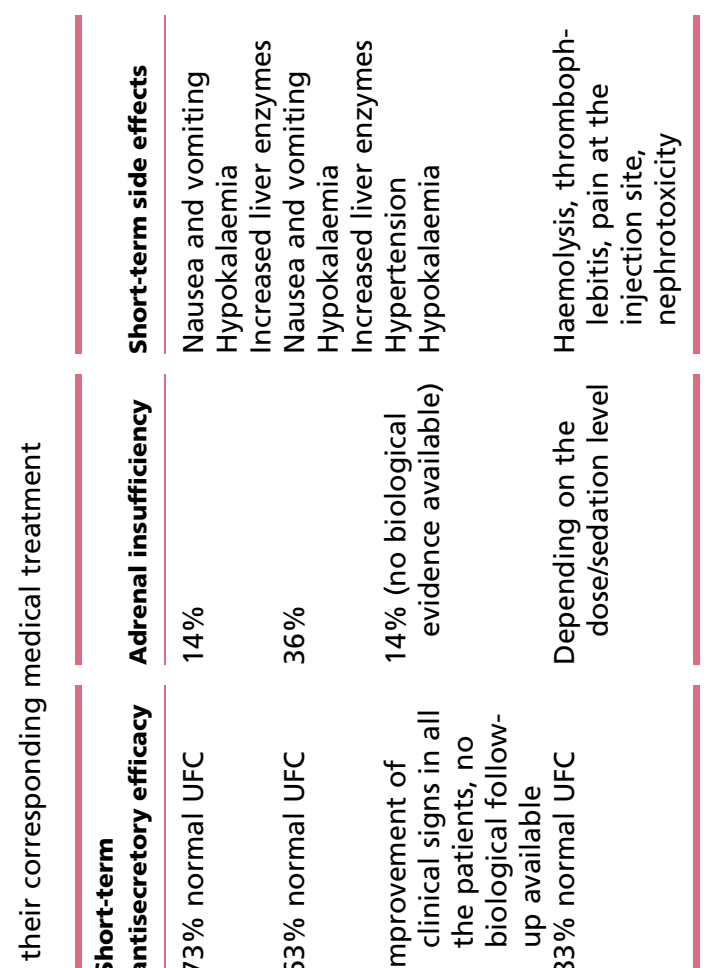

$\infty$

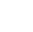
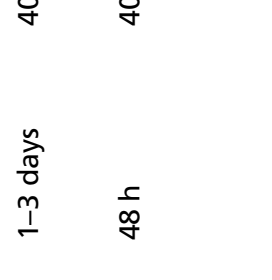

Other risks include pulmonary embolism, acute respiratory distress due to opportunistic infections, severe hypokalaemia, and uncontrolled diabetes and hypertension. In this setting, rapidly decreasing cortisol levels can be life-saving. However, no study compared the efficacy of supportive therapies associated with slow progressive decline of cortisol levels vs strategies resulting in an acute reversal of hypercortisolism. Case reports of fatal outcomes during acute phases of hypercortisolism prompted physicians to combine both supportive and medical cortisol-lowering options. BA has long been considered the gold standard. However, performing BA in these highly fragile patients can be challenging. Very fast-acting medical therapies have thus been considered as alternatives (see Table 2), as they allow for a rapid radical option after the control of hypersecretion, or to maintain their use on a long-term basis (detailed below).

Two studies reported the efficacy of the combination of steroidogenesis inhibitors: ketoconazole and metyrapone, both rapidly acting cytochrome P450 enzyme inhibitors, are administered to control hypercortisolism rapidly, while the maximal efficacy of mitotane is achieved later. The strategy is to maintain mitotane on a long-term basis and to withdraw metyrapone and ketoconazole after 2-3 months of effective therapy. The addition of mitotane is not always mandatory, as ketoconazole was shown to be effective in long-term therapy. A total of 24 patients with EAS $(n=21)$ or $\mathrm{CD}(n=3)$ and acute severe hypercortisolism were reported in two studies (Table 2): in the first study based on 14 patients with EAS, ketoconazole and metyrapone led to a decrease in urinary free cortisol (UFC) levels from 40- to 3.2-fold the upper limit of value (ULN) at the end of the first week; after 1 month, ten patients achieved normal UFC levels (Corcuff et al. 2015). In the second study of ten different patients, UFC levels dramatically decreased after $24-48 \mathrm{~h}$ in all patients, and seven patients achieved normal UFC levels; metyrapone and ketoconazole could be stopped after 3.5 months; control was maintained with mitotane alone (Kamenicky et al. 2011). In both studies, the overall tolerance was good: there were transient nausea and vomiting in the majority of patients and adrenal insufficiency in six patients; increased liver enzymes that were probably due to ketoconazole (greater than 3-fold the upper limit normal value) were also reported, but only two patients (including one who died rapidly due to liver metastases) had to withdraw from this drug. Most patients presented an initial worsening of hypokalaemia that could be controlled by oral potassium supplementation and/or a mineralocorticoid receptor antagonist. Interestingly, one-third of the patients were eventually treated by

Published by Bioscientifica Ltd. 
Table 3 Main studies reporting the outcomes of patients treated by unilateral adrenalectomy for BMAH

References

Debillon et al. (2015)

Albiger et al. (2015)

Li \& Yang (2015)

Xu et al. (2013)

Pooled data $(95 \% \mathrm{Cl})$

\begin{tabular}{ccc} 
Patients & & $\begin{array}{c}\text { Unilateral } \\
\text { adrenalectomy }\end{array}$ \\
\cline { 1 - 1 } 15 & & $15(100 \%)$ \\
16 & & $16(100 \%)$ \\
23 & & $15(65 \%)$ \\
14 & & $14(100 \%)$ \\
68 & & 60 \\
&
\end{tabular}

NA, not available.

\begin{tabular}{c}
$\begin{array}{c}\text { Corticotroph } \\
\text { suppression }\end{array}$ \\
\hline $2(13.3 \%)$ \\
NA \\
0 \\
$1(7 \%)$ \\
$7.8 \%$ \\
$(1.4-18.5 \%)$ \\
\hline
\end{tabular}

\begin{tabular}{c}
$\begin{array}{c}\text { Immediate } \\
\text { failure }\end{array}$ \\
\hline 0 \\
$1(6.2 \%)$ \\
0 \\
0 \\
$3 \%$ \\
$(0.3-8.5 \%)$ \\
\hline
\end{tabular}

\begin{tabular}{c} 
Recurrence \\
\hline $2(13.3 \%)$ \\
$8(50 \%)$ \\
$3(20 \%)$ \\
$1(7 \%)$ \\
$23.1 \%$ \\
$(8.7-41.8 \%)$ \\
\hline
\end{tabular}

Need for second surgery

$1(6.7 \%)$

$5(31 \%)$

$3(13 \%)$

$1(7 \%)$

$17.5 \%$

$(8.2-29.4 \%)$ tumour resection, whereas another third underwent BA once hypersecretion control was achieved (Kamenicky et al. 2011, Corcuff et al. 2015).

Mifepristone is currently the only available glucocorticoid receptor antagonist. Its very fast-acting efficacy in patients with cortisol-induced psychiatric disorders is very well known, as patients usually present dramatic improvement in 24-48 h. Mifepristone efficacy in controlling hyperglycaemia and hypertension was confirmed in a prospective study conducted in 50 patients with CS (mostly CD), but severe acute hypercortisolism was not specifically evaluated (Fleseriu et al. 2012). Mifepristone is usually well tolerated but is difficult to monitor: the glucocorticoid receptor blockade induces an increase in ACTH and subsequently in cortisol, making biological surveillance impossible to detect under- or over-therapy. Another frequently reported side effect was severe hypokalaemia and hypertension due to binding of high cortisol levels to mineralocorticoid receptors. In patients with severe hypercortisolism and hypokalaemia and hypertension, management with mifepristone could thus be highly challenging (Castinetti et al. 2009, 2012).
Etomidate is an imidazole derivative utilized as an intravenous hypnotic non-barbiturate induction anaesthetic agent; it was found to be an effective steroidogenesis inhibitor achieving a blockade in 12-24 h. Even if no report cited sedation when used as a treatment of severe hypercortisolism, etomidate is delivered in an intensive care unit to monitor vital signs and adrenal insufficiency. Etomidate use has been reported in 12 patients with severe hypercortisolism who were unable to take medications orally. The dose administered was $0.04-0.05 \mathrm{mg} / \mathrm{kg}$ per $\mathrm{h}$, with a cortisol titration (short half-life 3-5 h) and a frequent need for glucocorticoid replacement (in a block and replace strategy). Of note, severe hypercortisolism in an immobilized patient increases the risk of thromboembolic events, which should lead to the use of prophylactic heparin or low-molecular weight heparin (Preda et al. 2012).

To summarize, in our view, several studies based on a relatively low number of patients have shown promising results that fast-acting medical therapy can correct acute hypercortisolism. Monitoring these drugs is, however, challenging, and their use should be reserved to expert

Table 4 Summary of the efficacy and short- and long-term side effects of various medical therapies

\begin{tabular}{|c|c|c|}
\hline Medical therapy & Mechanism of action & $\begin{array}{l}\text { Long-term } \\
\text { antisecretory efficacy }\end{array}$ \\
\hline Ketoconazole & $\begin{array}{l}\text { Steroidogenesis } \\
\text { inhibitor }\end{array}$ & $50 \%$ \\
\hline Metyrapone & $\begin{array}{l}\text { Steroidogenesis } \\
\text { inhibitor }\end{array}$ & $83 \%$ \\
\hline LCI699 & $\begin{array}{l}\text { Steroidogenesis } \\
\text { inhibitor }\end{array}$ & $>80 \% ?$ \\
\hline Mitotane & $\begin{array}{l}\text { Steroidogenesis } \\
\text { inhibitor }\end{array}$ & $71 \%$ \\
\hline Cabergoline & D2 receptor agonist & $30-40 \% ?$ \\
\hline Pasireotide & $\begin{array}{l}\text { Somatostatin } \\
\text { analogue }\end{array}$ & $25 \% ?$ \\
\hline Mifepristone & $\begin{array}{l}\text { Glucocorticoid } \\
\text { receptor } \\
\text { antagonist }\end{array}$ & $\begin{array}{l}\text { Unknown long-term } \\
\text { blocking effect }\end{array}$ \\
\hline
\end{tabular}

\begin{tabular}{|c|c|}
\hline $\begin{array}{l}\text { Long-term specific } \\
\text { side effects }\end{array}$ & Escape \\
\hline- & $7 \%$ \\
\hline- & $?$ \\
\hline$?$ & $?$ \\
\hline $\begin{array}{l}\text { Adrenal } \\
\text { insufficiency? }\end{array}$ & $\begin{array}{l}\text { Low if threshold } \\
\text { obtained }\end{array}$ \\
\hline $\begin{array}{l}\text { Cardiac } \\
\text { valvulopathy? }\end{array}$ & $25 \% ?$ \\
\hline Gallstones? & $?$ \\
\hline $\begin{array}{l}\text { Endometrial } \\
\text { hyperplasia }\end{array}$ & $?$ \\
\hline
\end{tabular}

Published by Bioscientifica Ltd. 
centres: in this setting, BA can be delayed if a very rapid decrease in cortisol levels (in the first few days) is achieved. Drug intolerance or incomplete efficacy should lead to BA.

\section{BA in chronic hypercortisolism}

The management of $\mathrm{CD}$ is initially based on transsphenoidal pituitary surgery, which leads to an immediate remission rate of $50-80 \%$. Up to $25 \%$ of patients will, however, present recurrence during a long-term follow-up. Failed surgery can lead to different therapeutic options: radiotherapy and radiosurgery have shown antisecretory efficacy in $50-80 \%$ cases, but the delayed maximal efficacy (up to 3 years or more after the procedure) requires an effective medical treatment during this period of time. Another option is the long-term use of medical therapy. BA can be aimed i) at curing imperfectly controlled patients, in case of partial efficacy of medical therapy (with or without radiotherapy), or poor compliance; ii) or more controversially, at curing controlled patients. Although medical therapy can maintain long-term eucortisolism without significant side effects in some patients, some physicians might eventually recommend $\mathrm{BA}$, as withdrawal of these drugs would lead to a reappearance of the disease (Nieman et al. 2015, Pivonello et al. 2015).

The majority of the studies evaluating medical therapy of CS used UFC to evaluate the antisecretory efficacy. Petersenn et al. recently reported that there was a major intra-patient variability of $\sim 50 \%$ in 24 -h UFC measurement in CD. Repeating four measurements of UFC in the same patient, on medical treatment, did not decrease this variability. This probably means that very fluctuating levels of cortisol secretion may expose patients on medical therapy to fluctuate between under- and overtreatment with periods of adrenal insufficiency. This issue will have to be examined in prospective studies as part of the decision process when choosing between medical therapy and BA (Petersenn et al. 2014).

Efficacy and recurrence after BA BA leads to biological control immediately after surgery but implies the need for gluco- and mineralocorticoid replacement therapy in almost $100 \%$ of cases. Obtaining normal cortisol levels should lead to a complete remission of the manifestations of hypercortisolism during the 1st year of follow-up (Sippel et al. 2008). However, dependent on the period of exposure to high cortisol levels, a large majority of patients will not be completely cured of morbidities such as hypertension, diabetes, osteopenia or even psychiatric disturbances (Chow et al. 2008, Osswald et al. 2014). It is difficult to avoid the bias induced by the frequent glucocorticoid over-replacement, as this can, by itself, be responsible for the maintenance of such complications. Other studies have shown that the majority of patients were satisfied with a BA and had improved quality of life (Osswald et al. 2014).

While one should expect 100\% long-term remission after BA, recurrence has been reported in some cases after moderate to long-term follow-up. There is a clear distinction between an adrenal remnant without clinical significance (20-30\%) and the recurrence of hypercortisolism (1-3\%) (Nagesser et al. 2000, Chow et al. 2008) (Table 1). Defining the presence of an adrenal remnant is also controversial: some authors use a cut-off of plasma cortisol $>50 \mathrm{nmol} / \mathrm{l}$ after glucocorticoid withdrawal, others use the withdrawal or decreased glucocorticoid replacement therapy despite BA (Chalmers et al. 1981), and others recommend using NP53 scintigraphy to confirm the presence of an adrenal remnant (Kemink et al. 1992). Post-surgical remnants are usually due to difficult technical conditions such as intra-operative bleeding or poor visualization. While Chalmers et al. (1981) reported adrenal recurrence after BA in two patients with Nelson's syndrome, Kemink et al. (1992) did not find any difference in recurrence rates following BA in patients with Nelson's syndrome when compared with patients without progression of their corticotroph adenomas. The need for an additional treatment (e.g. repeating adrenal surgery to control clinically significant hypercortisolism) should be balanced by the benefits of obtaining eucortisolism in patients usually mildly oversecreting.

Our opinion is that endocrinologists should keep in mind that among patients with signs in favour of hydrocortisone overdose following BA, they should not hesitate to slowly decrease the dose of glucocorticoid replacement.

\section{Specific complications of BA}

The risk of Nelson's syndrome This topic has been recently reviewed, and we will thus not detail this specific point. The potential increase of a corticotroph adenoma remnant after BA justifies follow-up with appropriate ACTH measurement and pituitary magnetic resonance imaging (MRI); however, its rate is still debated, as well as the real risks for patients (Assie et al. 2007). The overall incidence is estimated to be $0-47 \%$ (median $21 \%$ ), and this wide range of variability is probably explained by different definitions of Nelson's syndrome. The visual risk associated with Nelson's syndrome is probably not an issue in the 21st

Published by Bioscientifica Ltd 
century, as endocrinologists are aware of this condition and regularly follow patients after surgery. This also probably explains why systematic pituitary radiotherapy is no longer advised in the management of such patients (Azad et al. 2015).

The outcome of patients with adrenal insufficiency The main issue after BA is obviously the need for an optimal replacement treatment. This optimal dose and restoration of normal cortisol diurnal rythm are difficult to achieve, but the impact of an over- or under-dose of hydrocortisone replacement is well described (Husebye et al. 2014). What was less obvious, and has been shown in a recent study, is that patients with adrenal insufficiency are at high risk for adrenal crises even if they receive education towards the management of their treatment: Hahner et al. (2015) reported a risk of 8.3 adrenal crises and a risk of 0.5 adrenal crisis-related deaths per 100 patients-year in 423 patients educated in an expert centre, while Ritzel's review showed a median number of 9.3 adrenal crises per 100 patientsyears (Ritzel et al. 2013). The overall outcome, however, remains good, with a relatively low rate of mortality.

\section{Comparison with long-term treatment with} medical therapy The aim of this review is not to discuss medical therapy (pituitary targeted, steroidogenesis inhibitors or glucocorticoid receptor antagonist) in the classical management of hypercortisolism. These issues have been reviewed recently (Creemers et al. 2015, Nieman et al. 2015, Pivonello et al. 2015). We have focused on the data concerning the long-term efficacy and tolerance of medical therapy in patients with CD or EAS to make a comparison between BA and long-term medical therapy in seemingly controlled patients.

In CD The majority of the published studies on medical therapy focused on short-term efficacy, and it is thus difficult to evaluate the risk of escape and long-term side effects. This is particularly the case for the novel pituitarytargeted somatostatin receptor multi-ligand Pasireotide, which demonstrated a $25 \%$ antisecretory efficacy in a large phase 3 international multi-centre study after 12 months of follow-up (Colao et al. 2012, Pivonello et al. 2014). Longterm data are also missing for mifepristone and cabergoline (Petrossians et al. 2010, Pivonello et al. 2015).

Data on the long-term efficacy and side effects of medical therapy are thus mainly based on the use of steroidogenesis inhibitors. In the largest study reported to date, mitotane was administered to 76 patients either as a first-line $(n=49)$ or as a second-line (after unsuccessful surgery, $n=27)$ treatment. Approximately three-quarters (76\%) of the patients were controlled on treatment at their last follow-up visit, and some patients were treated for $60-120$ months. Interestingly, five patients relapsed their hypercortisolism while on mitotane treatment when the dose was lowered because of side effects. The safety profile was unfortunately not provided based on the time after drug onset: the authors mentioned that serious adverse events leading to drug withdrawal were observed in $28 \%$ of the patients, including ten who were already in remission at the time of the side effects' occurrence. Mitotane is known to induce adrenal insufficiency, and one should wonder whether definite remission could be obtained after drug withdrawal: $71 \%$ of the patients presented with recurrent hypercortisolism, despite the fact that the majority of them had adrenal insufficiency at the time of drug withdrawal (Baudry et al. 2012). Of note, more than one-third of the patients finally had a BA during the follow-up.

Long-term ketoconazole use has also been reported recently. Of the 200 evaluated patients with $C D, 51$ were treated for at least 24 months (mean 108 months). At the last follow-up, $64 \%$ of the patients were controlled while $7 \%$ finally presented an escape to drug efficacy. The profile of side effects was favourable, provided that regular liver enzyme monitoring (which increased in $15.8 \%$ cases at the beginning of the treatment or dose change) is performed. No further increase in liver enzymes was reported on a long-term basis. No specific side effects were reported after 24 months of treatment. Of note, $4.4 \%$ of patients from the whole cohort underwent BA despite sustained antisecretory efficacy (Castinetti et al. 2014).

Finally, the largest UK multi-centre study on the use of metyrapone based on 115 patients with $\mathrm{CD}$ was reported recently. Using the average serum cortisol day curve $<12 \mu \mathrm{g} / \mathrm{dl}(331 \mathrm{nmol} / \mathrm{l})$ as the main response criteria, $55 \%$ of the patients achieved the target goal and were improved clinically. In a subgroup of 38 patients treated long-term (mean 18 months), 77\% were controlled. In the whole cohort, UFC levels were monitored only in 37 patients and decreased from 7.2- to 2.5-fold ULN; thus, despite clinical improvement, complete normalization of cortisol secretion may be incomplete. Metyrapone was generally well tolerated and the previously reported potential side effects of hypokalaemia, hypertension and hirsutism were not frequent; gastrointestinal upset (23\%) and hypoadrenalism (7\%) were the most frequent side effects (Daniel et al. 2015).

To summarize, data available on the long-term efficacy and safety of steroidogenesis inhibitors (at least for ketoconazole and metyrapone) do not provide

Published by Bioscientifica Ltd 
evidence for severe negative events during their maintenance. Such therapies could thus be maintained on a longterm basis. Their main advantage compared with BA is that they do not induce permanent adrenal insufficiency. Moreover, BA can still be considered in case of (rare) late escape. In contrast, specific conditions such as a young woman not cured by pituitary surgery and wishing a pregnancy would be a good indication for BA if residual resectable corticotroph adenoma is not an option. Poor drug compliance, financial restrictions to long-term use of steroidogenic inhibitors and very high cyclic ACTH and cortisol secretion requiring the block and replace therapy could also be conditions to recommend BA.

In EAS Data on the long-term efficacy of medical therapy in occult EAS are scarce, probably because clinicians prefer to perform BA rapidly. EAS includes aggressive poorly differentiated tumours (e.g. small-cell lung carcinoma) and well-differentiated neuroendocrine tumours (carcinoids). While the main issue is the difficulty in performing complete surgical excision in the former, the latter are usually small and difficult to visualize with classical imaging techniques and have a low progression rate. Conventional morphological imaging modalities such as computed tomography (CT) and MRI may be falsely negative. As much as $12-19 \%$ of EAS remains occult (Alexandraki \& Grossman 2010). The utility of somatostatin receptor scintigraphy with $\left[{ }^{111}\right.$ In]pentetreotide for the localization of EAS has been ambiguous (Tabarin et al. 1999, Torpy et al. 1999). Somatostatin receptor scintigraphy (Octreoscan) has been used, in addition to CT and MRI, for the localization of EAS (de Herder et al. 1994, Phlipponneau et al. 1994). In a systematic review, molecular imaging discovered $79.1 \%$ of tumours unidentified by conventional radiology. The tumours were localized by CT in $66.2 \%$ of cases, MRI in $51.5 \%$ of cases and Octreoscan in $48.9 \%$ of cases (Isidori et al. 2015). Hybrid PET/CT combining functional imaging (PET) with integrated anatomical imaging (CT) provides an advantage over conventional imaging alone and appears to be ideal for the localization of EAS (Rufini et al. 2006, Santhanam et al. 2015). $\left[{ }^{18} \mathrm{~F}\right] \mathrm{FDG}$ PET/CT sensitivity is high in small-cell lung neuroendocrine tumours, atypical thymic tumours and aggressive medullary thyroid carcinoma, but tumour uptake might be very low in welldifferentiated/low-grade neuroendocrine tumours. $\left[{ }^{18} \mathrm{~F}\right]$ DOPA PET seems to have a moderate detection rate (57.1\%) for EAS despite some positive cases.

When the tumour is not visualized, medical therapy can be provided. Sharma \& Nieman (2012) reported the partial/total efficacy of steroidogenesis inhibitors in four patients treated by ketoconazole alone or with mitotane and/or metyrapone after 15-60 months. The first patient was considered to be in remission after 6 years of drugs but ultimately relapsed and was treated by a BA; the three others were considered to be in remission 24-60 months after drugs withdrawal. Isidori et al. (2006) in a large study based on 40 patients, mentioned that 28 patients were successfully controlled by metyrapone, associated with ketoconazole and/or mitotane, for 4 weeks to 96 months, without any serious adverse effect. Some case reports described a rapid antisecretory efficacy of octreotide and/or cabergoline before surgery, but long-term data were missing. These drugs cannot be considered as firstline treatments but could be delivered when other drugs are not effective, in aggressive tumours with metastases, or when parenteral administration is required (for octreotide) (de Bruin et al. 2009).

To summarize, progress in imaging techniques to identify the source of ACTH secretion might decrease the time before surgical resection of the tumour. The possibility of long-term efficacy of medical therapy (or even potential remission by still imperfectly understood mechanisms) should lead physicians to be more cautious with the indication of rapid BA, provided the patient responds favourably to an effective medical therapy.

\section{Comparison with new radiotherapy moda-}

lities Recent studies on the use of new radiation techniques (Gamma Knife radiosurgery or fractionated stereotactic radiation therapy) have clarified their efficacy and side effects in comparison with conventional radiotherapy. The main advantage of stereotactic procedures is that the target is precisely defined, and this decreases the rate of side effects (mainly hypopituitarism).

The majority of the studies on long-term efficacy were based on Gamma Knife radiosurgery, but it is likely that similar results would be observed with the other techniques. Antisecretory efficacy has been reported in $40-60 \%$ of cases. Compared with conventional radiotherapy, the time to remission is shorter and is estimated to be $2-4$ years. This remains a major issue, as it means that the patient will need effective medical therapy during this period of time. In addition, recurrence has been reported in up to $20 \%$ of cases, 3-5 years after remission. The safety profile has drastically improved, with only $20 \%$ of patients experiencing new pituitary deficiencies and the lack - at least after 10 years of follow-up - of extrapituitary side effects (Minniti et al. 2009, Castinetti et al. 2010).

Published by Bioscientifica Ltd. 
To summarize, the low rate of side effects with new radiation techniques should lead to a more frequent use of such options, provided the fact that an obvious target is visualized and an effective medical therapy is available for 2-5 years. BA will remain an option for those in whom radiotherapy failed to control hypercortisolism after this delay.

Is there a need to achieve eucortisolism in patients scheduled for BA? Preparing the patient before any surgical treatment of hypercortisolism is debated, and this also concerns BA. It is indeed still not known whether patients presenting with eucortisolism at the time of surgery will have a better outcome after BA. The only dedicated study was based on the use of ketoconazole and/or metyrapone before transsphenoidal surgery: 52 patients were evaluated retrospectively after a mean period of 4 months on steroidogenesis inhibitors. Approximately one-half $(51 \%)$ were controlled clinically and biologically at the time of surgery. The overall rate of recurrence was similar in each group. The authors reported that hypertension was more persistent in patients without pretreatment up to 108 months after surgery. They also suggested that pretreatment could decrease the rate of thrombo-embolic events, but the number of events was very low (Valassi et al. 2012). Thrombo-embolic events are a well-identified potential complication of surgery for hypercortisolism: of the 1162 patients evaluated in the hypercortisolism literature, $7.2 \%$ had a thrombo-embolic event, $33 \%$ of which occurred in the year following surgery (Coelho et al. 2015); thus, adequate thromboprophylaxis is recommended (Nieman et al. 2015). The benefit of pretreatment was also questioned by the fact that the group of patients with partially controlled hypersecretion (UFC decrease without normal levels) with the pretreatment had a worse clinical outcome than untreated patients (Valassi et al. 2012). Finally, Ritzel et al. (2013) reviewed the morbidity and mortality rates in patients treated with BA to determine whether they were treated by medical therapy: in 22 studies based on 556 patients without pretreatment, the morbidity rate was $19 \%$ and the mortality rate was $<1 \%$, which was roughly comparable to the findings of the six studies that reported the pretreatment outcomes of 249 patients, with $21 \%$ of morbidity and $2 \%$ of mortality rates.

To summarize, even if achieving eucortisolism before BA appears to be a logical goal, there are no strong data in favour of a better post-surgical outcome: in acute severe hypercortisolism, BA should be performed, as mentioned previously, whatever the level of cortisol, if medical treatment is not rapidly effective. Trying to obtain eucortisolism should not delay the surgery. However, medical therapy is indicated in patients in whom surgery has to be delayed for specific medical comorbidities such as recent pulmonary embolism.

\section{BA in primary bilateral adrenal hyperplasias}

Historically, BA has been considered the first-line treatment for patients with BMAH and overt CS. Cortisol excess is usually modest in BMAH, even in those with elevated UFC levels; this has led to the attempts to use unilateral adrenalectomy, particularly when UFC levels were $<2-3$ times ULN (Lacroix et al. 2015). Recently, the role of unilateral adrenalectomy in these patients was assessed in a small series of patients, summarized in Table 4 (Xu et al. 2013, Albiger et al. 2015, Li \& Yang 2015). Very recently, Debillon et al. (2015) reported their experience in 15 patients with BMAH treated by unilateral adrenalectomy: resection of the larger gland led to a 3-month post-surgical remission of hypercortisolism in $100 \%$ of cases and a low risk of recurrence after 7-9 years of follow-up $(n=2)$. The question of which gland to operate on is still a matter of debate. Debillon et al. chose to operate the largest gland on CT, which, in more than $50 \%$ of cases, was also the gland with the largest cholesterol uptake in adrenal scintigraphy. The potential benefit of adrenal scintigraphy is counterbalanced by the fact that the uptake is usually correlated with the volume of the gland, thus, stronger uptake does not necessarily correspond with superior secretory activity. One point to emphasize is the risk of adrenal insufficiency after unilateral adrenalectomy for BMAH: Debillon et al. (2015) indeed reported 40\% of cases after surgery: even if half of them finally recovered, a peculiar surveillance should be performed post-operatively in all patients treated by unilateral adrenalectomy.

As recently underlined by the Endocrine Society Guidelines (Nieman et al. 2015), BA should be preferred in adult patients with PPNAD: the risk of recurrence after unilateral adrenalectomy is indeed much higher and occurs much earlier, as there is usually an increased activity of the overall adrenal tissue (Vezzosi et al. 2015).

To summarize, the rarity of the published data makes it difficult to determine the outcomes of patients who undergo unilateral adrenalectomy for BMAH with modest hypercortisolism. It is likely that these patients will eventually present with recurrence, requiring a contralateral adrenalectomy. The time to recurrence is variable, from 3 to 10 years after surgery. These patients thus require a close biological follow-up. On the other hand, such

Published by Bioscientifica Ltd 
patients will gain 3-10 years without adrenal insufficiency, and this is strong evidence in favour of the use of unilateral adrenalectomy as a first-line treatment in BMAH. Unilateral adrenalectomy seems to be more efficient when there is asymmetric adrenal involvement. In rare patients with severe $\mathrm{CS}$ and BMAH and symmetrically enlarged adrenals, BA is still recommended. BA is indicated in patients with PPNAD or other forms of bilateral micronodular hyperplasia.

\section{Conclusions and perspectives}

Bilateral laparoscopic adrenalectomy is the most effective definitive treatment of hypercortisolism when surgical removal of the source of excess ACTH is not possible. It is a rapidly acting technique, which, in experienced hands, should be considered safe. However, several other options are currently available, which, again in experienced hands, showed results that might modify the first/last options in the therapeutic algorithm of hypercortisolism. Defining the place of $\mathrm{BA}$ in the 21st century is thus challenging. It might be even more difficult in the future with long-term results on the efficacy of new drugs such as LCI699, a long-acting release form of Pasireotide, or potentially less toxic formulations of ketoconazole. All of these results might guide clinicians towards a prolonged 'wait and see' approach rather than radical treatments. From an imaging viewpoint, somatostatin agonists labelled with $68 \mathrm{Ga}$ have shown very promising results in detecting endocrine tumours and need to be further evaluated in clinical settings: this might help earlier localization of an ACTH tumour source in EAS. In $\mathrm{BMAH}$, preoperative assessment of the degree of functionality of each adrenal could guide surgeons towards the most appropriate management and could predict residual cortical function after unilateral adrenalectomy. To this end, high-affinity PET ligands for the LDL-C receptor and steroidogenic enzymes ([$\left.{ }^{11} \mathrm{C}\right]$ metomidate) or chemokine ligands may help clinicians choose unilateral adrenalectomy rather than $\mathrm{BA}$. Moreover, the understanding of the genetic mechanisms involved in BMAH such as ARMC5 mutations will help researchers understand the natural history of such lesions and will provide guidance towards early detection of affected individuals and personalized therapy to avoid morbidities of cortisol excess.

\section{Declaration of interest}

$T$ Brue, A Lacroix and $F$ Castinetti received funding from Novartis to conduct clinical studies with Pasireotide and LCl699 in Cushing's disease and from Cortendo for studies on levoketoconazole in Cushing's syndrome. C Guerin, D Taieb, G Treglia and F Sebag declare that they have no conflict of interest.

\section{Funding}

This review did not receive any specific grant from any funding agency in the public, commercial or not-for-profit sector.

Author contribution statement

C Guerin, D Taieb and F Castinetti designed the review, made the search, drafted and critically reviewed the report, and approved the final version. G Treglia performed the pooled analysis. G Treglia, T Brue, A Lacroix and F Sebag drafted and critically reviewed the report, and approved the final version.

\section{References}

Albiger NM, Ceccato F, Zilio M, Barbot M, Occhi G, Rizzati S, Fassina A, Mantero F, Boscaro M, Iacobone M et al. 2015 An analysis of different therapeutic options in patients with Cushing's syndrome due to bilateral macronodular adrenal hyperplasia: a single-centre experience. Clinical Endocrinology 82 808-815. (doi:10.1111/cen.12763)

Alexandraki KI \& Grossman AB 2010 The ectopic ACTH syndrome. Reviews in Endocrine \& Metabolic Disorders 11 117-126. (doi:10.1007/ s11154-010-9139-z)

Andela CD, van Haalen FM, Ragnarsson O, Papakokkinou E, Johannsson G Santos A, Webb SM, Biermasz NR, van der Wee NJ \& Pereira AM 2015 Mechanisms in Endocrinology: Cushing's syndrome causes irreversible effects on the human brain: a systematic review of structural and functional magnetic resonance imaging studies. European Journal of Endocrinology 173 R1-14. (doi:10.1530/EJE-14-1101)

Assie G, Antoni G, Tissier F, Caillou B, Abiven G, Gicquel C, Leboulleux S, Travagli JP, Dromain C, Bertagna X et al. 2007 Prognostic parameters of metastatic adrenocortical carcinoma. Journal of Clinical Endocrinology and Metabolism 92 148-154. (doi:10.1210/jc.2006-0706)

Assie G, Libe R, Espiard S, Rizk-Rabin M, Guimier A, Luscap W, Barreau O, Lefevre L, Sibony M, Guignat L et al. 2013 ARMC5 mutations in macronodular adrenal hyperplasia with Cushing's syndrome. New England Journal of Medicine 369 2105-2114. (doi:10.1056/ NEJMoa1304603)

Azad TD, Veeravagu A, Kumar S \& Katznelson L 2015 Nelson syndrome: update on therapeutic approaches. World Neurosurgery 83 1135-1140. (doi:10.1016/j.wneu.2015.01.038)

Baudry C, Coste J, Bou Khalil R, Silvera S, Guignat L, Guibourdenche J, Abbas H, Legmann P, Bertagna X \& Bertherat J 2012 Efficiency and tolerance of mitotane in Cushing's disease in 76 patients from a single center. European Journal of Endocrinology 167 473-481. (doi:10.1530/ EJE-12-0358)

Bertagna X \& Guignat L 2013 Approach to the Cushing's disease patient with persistent/recurrent hypercortisolism after pituitary surgery. Journal of Clinical Endocrinology and Metabolism 98 1307-1318. (doi:10.1210/jc.2012-3200)

Bertherat J 2006 Carney complex (CNC). Orphanet Journal of Rare Diseases $\mathbf{1}$ 21. (doi:10.1186/1750-1172-1-21)

de Bruin C, Feelders RA, Lamberts SW \& Hofland LJ 2009 Somatostatin and dopamine receptors as targets for medical treatment of Cushing's Syndrome. Reviews in Endocrine \& Metabolic Disorders 10 91-102. (doi:10.1007/s11154-008-9082-4)

Castinetti F, Fassnacht M, Johanssen S, Terzolo M, Bouchard P, Chanson P, Do Cao C, Morange I, Pico A, Ouzounian S et al. 2009 Merits and 
pitfalls of mifepristone in Cushing's syndrome. European Journal of Endocrinology 160 1003-1010. (doi:10.1530/EJE-09-0098)

Castinetti F, Regis J, Dufour H \& Brue T 2010 Role of stereotactic radiosurgery in the management of pituitary adenomas. Nature Reviews. Endocrinology 6 214-223. (doi:10.1038/nrendo.2010.4)

Castinetti F, Brue T \& Conte-Devolx B 2012 The use of the glucocorticoid receptor antagonist mifepristone in Cushing's syndrome. Current Opinion in Endocrinology, Diabetes, and Obesity 19 295-299. (doi:10.1097/MED.0b013e32835430bf)

Castinetti F, Guignat L, Giraud P, Muller M, Kamenicky P, Drui D, Caron P, Luca F, Donadille B, Vantyghem MC et al. 2014 Ketoconazole in Cushing's disease: is it worth a try? Journal of Clinical Endocrinology and Metabolism 99 1623-1630. (doi:10.1210/jc.2013-3628)

Chalmers RA, Mashiter K \& Joplin GF 1981 Residual adrenocortical function after bilateral "total" adrenalectomy for Cushing's disease. Lancet 2 1196-1199. (doi:10.1016/S0140-6736(81)91438-0)

Chow JT, Thompson GB, Grant CS, Farley DR, Richards ML \& Young WF Jr 2008 Bilateral laparoscopic adrenalectomy for corticotrophindependent Cushing's syndrome: a review of the Mayo Clinic experience. Clinical Endocrinology 68 513-519. (doi:10.1111/j.13652265.2007.03082.x

Coelho MC, Santos CV, Neto LV \& Gadelha MR 2015 Adverse effects of glucocorticoids: coagulopathy. European Journal of Endocrinology 173 M11-M21. (doi:10.1530/EJE-15-0198)

Colao A, Petersenn S, Newell-Price J, Findling JW, Gu F, Maldonado M, Schoenherr U, Mills D, Salgado LR \& Biller BM 2012 A 12-month phase 3 study of pasireotide in Cushing's disease. New England Journal of Medicine 366 914-924. (doi:10.1056/NEJMoa1105743)

Corcuff JB, Young J, Masquefa-Giraud P, Chanson P, Baudin E \& Tabarin A 2015 Rapid control of severe neoplastic hypercortisolism with metyrapone and ketoconazole. European Journal of Endocrinology 172 473-481. (doi:10.1530/EJE-14-0913)

Creemers SG, Hofland LJ, Lamberts SW \& Feelders RA 2015 Cushing's syndrome: an update on current pharmacotherapy and future directions. Expert Opinion on Pharmacotherapy 16 1829-1844.

Daniel E, Aylwin S, Mustafa O, Ball S, Munir A, Boelaert K, Chortis V, Cuthbertson DJ, Daousi C, Rajeev SP et al. 2015 Effectiveness of metyrapone in treating Cushing's Syndrome: a retrospective multicenter study in 195 patients. Journal of Clinical Endocrinology and Metabolism 100 4146-4154. (doi:10.1210/jc.2015-2616)

Debillon E, Velayoudom-Cephise FL, Salenave S, Caron P, Chaffanjon P, Wagner T, Massoutier M, Lambert B, Benoit M, Young J et al. 2015 Unilateral adrenalectomy as a first-line treatment of Cushing's syndrome in patients with primary bilateral macronodular adrenal hyperplasia. Journal of Clinical Endocrinology and Metabolism $\mathbf{1 0 0}$ 4417-4424. (doi:10.1210/jc.2015-2662)

Fleseriu M, Biller BM, Findling JW, Molitch ME, Schteingart DE \& Gross C 2012 Mifepristone, a glucocorticoid receptor antagonist, produces clinical and metabolic benefits in patients with Cushing's syndrome. Journal of Clinical Endocrinology and Metabolism 97 2039-2049. (doi:10.1210/jc.2011-3350)

Gagner M, Lacroix A \& Bolte E 1992 Laparoscopic adrenalectomy in Cushing's syndrome and pheochromocytoma. New England Journal of Medicine 327 1033. (doi:10.1056/NEJM199210013271417)

Hahner S, Spinnler C, Fassnacht M, Burger-Stritt S, Lang K, Milovanovic D, Beuschlein F, Willenberg HS, Quinkler M \& Allolio B 2015 High incidence of adrenal crisis in educated patients with chronic adrenal insufficiency: a prospective study. Journal of Clinical Endocrinology and Metabolism 100 407-416. (doi:10.1210/jc.2014-3191)

de Herder WW, Krenning EP, Malchoff CD, Hofland LJ, Reubi JC, Kwekkeboom DJ, Oei HY, Pols HA, Bruining HA, Nobels FR et al. 1994 Somatostatin receptor scintigraphy: its value in tumor localization in patients with Cushing's syndrome caused by ectopic corticotropin or corticotropin-releasing hormone secretion. American Journal of Medicine 96 305-312. (doi:10.1016/0002-9343(94)90059-0)
Husebye ES, Allolio B, Arlt W, Badenhoop K, Bensing S, Betterle C, Falorni A, Gan EH, Hulting AL, Kasperlik-Zaluska A et al. 2014 Consensus statement on the diagnosis, treatment and follow-up of patients with primary adrenal insufficiency. Journal of Internal Medicine 275 104-115. (doi:10.1111/joim.12162)

Isidori AM, Kaltsas GA, Pozza C, Frajese V, Newell-Price J, Reznek RH, Jenkins PJ, Monson JP, Grossman AB \& Besser GM 2006 The ectopic adrenocorticotropin syndrome: clinical features, diagnosis, management, and long-term follow-up. Journal of Clinical Endocrinology and Metabolism 91 371-377. (doi:10.1210/jc.2005-1542)

Isidori AM, Sbardella E, Zatelli MC, Boschetti M, Vitale G, Colao A \& Pivonello R 2015 Conventional and nuclear medicine imaging in ectopic Cushing's syndrome: a systematic review. Journal of Clinical Endocrinology and Metabolism 100 3231-3244. (doi:10.1210/ JC.2015-1589)

Kamenicky P, Droumaguet C, Salenave S, Blanchard A, Jublanc C, Gautier JF, Brailly-Tabard S, Leboulleux S, Schlumberger M, Baudin E et al. 2011 Mitotane, metyrapone, and ketoconazole combination therapy as an alternative to rescue adrenalectomy for severe ACTH-dependent Cushing's syndrome. Journal of Clinical Endocrinology and Metabolism 96 2796-2804. (doi:10.1210/jc.2011-0536)

Katznelson L 2015 Bilateral adrenalectomy for Cushing's disease. Pituitary 18 269-273. (doi:10.1007/s11102-014-0633-2)

Kemink L, Hermus A, Pieters G, Benraad T, Smals A \& Kloppenborg P 1992 Residual adrenocortical function after bilateral adrenalectomy for pituitary-dependent Cushing's syndrome. Journal of Clinical Endocrinology and Metabolism 75 1211-1214.

Lacroix A, Feelders RA, Stratakis CA \& Nieman LK 2015 Cushing's syndrome. Lancet 386 913-927. (doi:10.1016/S0140-6736(14)61375-1)

Lan BY, Taskin HE, Aksoy E, Birsen O, Dural C, Mitchell J, Siperstein A \& Berber E 2015 Factors affecting the surgical approach and timing of bilateral adrenalectomy. Surgical Endoscopy 29 1741-1745. (doi:10.1007/s00464-014-3891-1)

Li J \& Yang CH 2015 Diagnosis and treatment of adrenocorticotrophic hormone-independent macronodular adrenocortical hyperplasia: a report of 23 cases in a single center. Experimental and Therapeutic Medicine 9 507-512.

Louiset E, Duparc C, Young J, Renouf S, Tetsi Nomigni M, Boutelet I, Libe R, Bram Z, Groussin L, Caron P et al. 2013 Intraadrenal corticotropin in bilateral macronodular adrenal hyperplasia. New England Journal of Medicine 369 2115-2125. (doi:10.1056/NEJMoa1215245)

Miccoli P, Materazzi G, Brauckhoff M, Ambrosini CE, Miccoli M \& Dralle H 2011 No outcome differences between a laparoscopic and retroperitoneoscopic approach in synchronous bilateral adrenal surgery. World Journal of Surgery 35 2698-2702. (doi:10.1007/s00268-0111294-1)

Minniti G, Gilbert DC \& Brada M 2009 Modern techniques for pituitary radiotherapy. Reviews in Endocrine \& Metabolic Disorders 10 135-144. (doi:10.1007/s11154-008-9106-0)

Nagesser SK, van Seters AP, Kievit J, Hermans J, Krans HM \& van de Velde CJ 2000 Long-term results of total adrenalectomy for Cushing's disease. World Journal of Surgery 24 108-113. (doi:10.1007/s002689910020)

Neychev V, Steinberg SM, Yang L, Mehta A, Nilubol N, Keil MF, Nieman L, Stratakis CA \& Kebebew E 2015 Long-term outcome of bilateral laparoscopic adrenalectomy measured by disease-specific questionnaire in a unique group of patients with Cushing's syndrome. Annals of Surgical Oncology 22 (Suppl 3) 699-706. (doi:10.1245/s10434-015-4605-1)

Nieman LK, Biller BM, Findling JW, Murad MH, Newell-Price J, Savage MO \& Tabarin A 2015 Treatment of Cushing's syndrome: an endocrine society clinical practice guideline. Journal of Clinical Endocrinology and Metabolism 100 2807-2831. (doi:10.1210/jc.2015-1818)

Ntali G, Asimakopoulou A, Siamatras T, Komninos J, Vassiliadi D, Tzanela M, Tsagarakis S, Grossman AB, Wass JA \& Karavitaki N 2013 Mortality in Cushing's syndrome: systematic analysis of a large series with prolonged follow-up. European Journal of Endocrinology 169 715-723. (doi:10.1530/EJE-13-0569) 
Osswald A, Plomer E, Dimopoulou C, Milian M, Blaser R, Ritzel K, Mickisch A, Knerr F, Stanojevic M, Hallfeldt K et al. 2014 Favorable long-term outcomes of bilateral adrenalectomy in Cushing's disease. European Journal of Endocrinology 171 209-215. (doi:10.1530/ EJE-14-0214)

Petersenn S, Newell-Price J, Findling JW, Gu F, Maldonado M, Sen K, Salgado LR, Colao A \& Biller BM 2014 High variability in baseline urinary free cortisol values in patients with Cushing's disease. Clinical Endocrinology 80 261-269. (doi:10.1111/cen.12259)

Petrossians P, Thonnard AS \& Beckers A 2010 Medical treatment in Cushing's syndrome: dopamine agonists and cabergoline. Neuroendocrinology 92 (Suppl 1) 116-119. (doi:10.1159/000317716)

Phlipponneau M, Nocaudie M, Epelbaum J, De Keyzer Y, Lalau JD, Marchandise X \& Bertagna X 1994 Somatostatin analogs for the localization and preoperative treatment of an adrenocorticotropinsecreting bronchial carcinoid tumor. Journal of Clinical Endocrinology and Metabolism 78 20-24.

Pivonello R, Petersenn S, Newell-Price J, Findling JW, Gu F, Maldonado M, Trovato A, Hughes G, Salgado LR, Lacroix A et al. 2014 Pasireotide treatment significantly improves clinical signs and symptoms in patients with Cushing's disease: results from a Phase III study. Clinical Endocrinology 81 408-417. (doi:10.1111/cen.12431)

Pivonello R, De Leo M, Cozzolino A \& Colao A 2015 The treatment of Cushing's disease. Endocrine Reviews 36 385-486. (doi:10.1210/er. 2013-1048)

Preda VA, Sen J, Karavitaki N \& Grossman AB 2012 Etomidate in the management of hypercortisolaemia in Cushing's syndrome: a review. European Journal of Endocrinology 167 137-143. (doi:10.1530/EJE-120274)

Raffaelli M, Brunaud L, De Crea C, Hoche G, Oragano L, Bresler L, Bellantone R \& Lombardi CP 2014 Synchronous bilateral adrenalectomy for Cushing's syndrome: laparoscopic versus posterior retroperitoneoscopic versus robotic approach. World Journal of Surgery 38 709-715. (doi:10.1007/s00268-013-2326-9)

Reincke M, Ritzel K, Osswald A, Berr C, Stalla G, Hallfeldt K, Reisch N, Schopohl J \& Beuschlein F 2015 A critical reappraisal of bilateral adrenalectomy for ACTH-dependent Cushing's syndrome. European Journal of Endocrinology 173 M23-M32. (doi:10.1530/EJE-15-0265)

Ritzel K, Beuschlein F, Mickisch A, Osswald A, Schneider HJ, Schopohl J \& Reincke M 2013 Clinical Review: Outcome of bilateral adrenalectomy in Cushing's syndrome: a systematic review. Journal of Clinical Endocrinology and Metabolism 98 3939-3948. (doi:10.1210/ jc.2013-1470)

Rufini V, Calcagni ML \& Baum RP 2006 Imaging of neuroendocrine tumors. Seminars in Nuclear Medicine 36 228-247. (doi:10.1053/ j.semnuclmed.2006.03.007)
Russell CF, Hamberger B, van Heerden JA, Edis AJ \& Ilstrup DM 1982 Adrenalectomy: anterior or posterior approach? American Journal of Surgery 144 322-324. (doi:10.1016/0002-9610(82)90010-1)

Santhanam P, Taieb D, Giovanella L \& Treglia G 2015 PET imaging in ectopic Cushing syndrome: a systematic review. Endocrine 50 297-305. (doi:10.1007/s12020-015-0689-4)

Sharma ST \& Nieman LK 2012 Prolonged remission after long-term treatment with steroidogenesis inhibitors in Cushing's syndrome caused by ectopic ACTH secretion. European Journal of Endocrinology 166 531-536. (doi:10.1530/EJE-11-0949)

Sharma R, Ganpule A, Veeramani M, Sabnis RB \& Desai M 2009 Laparoscopic management of adrenal lesions larger than $5 \mathrm{~cm}$ in diameter. Urology Journal 6 254-259.

Sippel RS, Elaraj DM, Kebebew E, Lindsay S, Tyrrell JB \& Duh QY 2008 Waiting for change: symptom resolution after adrenalectomy for Cushing's syndrome. Surgery 144 1054-1060; discussion 1060-1051. (doi:10.1016/j.surg.2008.08.024)

Tabarin A, Valli N, Chanson P, Bachelot Y, Rohmer V, Bex-Bachellerie V, Catargi B, Roger P \& Laurent F 1999 Usefulness of somatostatin receptor scintigraphy in patients with occult ectopic adrenocorticotropin syndrome. Journal of Clinical Endocrinology and Metabolism $\mathbf{8 4}$ 1193-1202. (doi:10.1210/jcem.84.4.5583)

Torpy DJ, Chen CC, Mullen N, Doppman JL, Carrasquillo JA, Chrousos GP \& Nieman LK 1999 Lack of utility of (111)In-pentetreotide scintigraphy in localizing ectopic ACTH producing tumors: follow-up of 18 patients. Journal of Clinical Endocrinology and Metabolism 84 1186-1192. (doi:10.1210/jcem.84.4.5576)

Valassi E, Crespo I, Gich I, Rodriguez J \& Webb SM 2012 A reappraisal of the medical therapy with steroidogenesis inhibitors in Cushing's syndrome. Clinical Endocrinology 77 735-742. (doi:10.1111/j.1365-2265. 2012.04424.x)

Vezzosi D, Tenenbaum F, Cazabat L, Tissier F, Bienvenu M, Carrasco CA, Laloi-Michelin M, Barrande G, Lefebvre H, Hieronimus S et al. 2015 Hormonal, radiological, NP-59 scintigraphy and pathological correlations in patients with Cushing's syndrome due to Primary Pigmented Nodular Adrenocortical Disease (PPNAD). Journal of Clinical Endocrinology and Metabolism 100 4332-4338. (doi:10.1210/jc.2015-2174)

Wong A, Eloy JA \& Liu JK 2015 The role of bilateral adrenalectomy in the treatment of refractory Cushing's disease. Neurosurgical Focus 38 E9. (doi:10.3171/2014.10.FOCUS14684)

Xu Y, Rui W, Qi Y, Zhang C, Zhao J, Wang X, Wu Y, Zhu Q, Shen Z, Ning G et al. 2013 The role of unilateral adrenalectomy in corticotropinindependent bilateral adrenocortical hyperplasias. World Journal of Surgery 37 1626-1632. (doi:10.1007/s00268-013-2059-9)

Young H 1936 Technique for simultaneous exposure and operation on adrenals. Surgery 63119.

Received in final form 30 November 2015

Accepted 3 December 2015
(C) 2016 Society for Endocrinology Printed in Great Britain 